IRA-International Journal of Education \& Multidisciplinary Studies

ISSN 2455-2526; Vol.13, Issue 03 (December, 2018)

Pg. no. 48-53.

Institute of Research Advances

Institute of

http://research-advances.org/index.php/IJEMS

\title{
Implication of Class-Based Assessment on Teachers: A Case Study
}

\author{
Feroz Mohammed $\mathrm{Ali}^{1 \#} \&$ MD Asif lqubal ${ }^{2}$ \\ ${ }^{1}$ Lecturer, Department of Secondary Education, Fiji National University, Fiji. \\ ${ }^{2}$ Assistant Professor, Department of Social Science, Fiji National University, Fiji. \\ \#corresponding author. \\ Type of Review: Peer Reviewed. \\ DOl: http://dx.doi.org/10.21013/jems.v13.n3.p3
}

\section{How to cite this paper:}

Ali, F.M., Iqubal, M.A. (2018). Implication of Class-Based Assessment on Teachers: A Case Study. IRA International Journal of Education and Multidisciplinary Studies (ISSN 2455-2526), 13(3), 48-53.doi: http://dx.doi.org/10.21013/jems.v13.n3.p3

(C) Institute of Research Advances.

This work is licensed under a Creative Commons Attribution-Non Commercial 4.0 International License subject to a proper citation to the publication source of the work.

Disclaimer: The scholarly papers as reviewed and published by the Institute of Research Advances (IRA) are the views and opinions of their respective authors and are not the views or opinions of the IRA. The IRA disclaims of any harm or loss caused due to the published content to any party.

Institute of Research Advances is an institutional publisher member of Publishers Inter Linking Association Inc. (PILA-CrossRef), USA. The institute is an institutional signatory to the Budapest Open Access Initiative, Hungary advocating the open access of scientific and scholarly knowledge. The Institute is a registered content provider under Open Access Initiative Protocol for Metadata Harvesting (OAI-PMH).

The journal is indexed \& included in WorldCat Discovery Service (USA), CrossRef Metadata Search (USA), WorldCat (USA), OCLC (USA), Open J-Gate (India), EZB (Germany) Scilit (Switzerland), Airiti (China), Bielefeld Academic Search Engine (BASE) of Bielefeld University, Germany, PKP Index of Simon Fraser University, Canada. 


\begin{abstract}
In Fiji, assessment has always been guided by curriculum through examination and tests which merely enclosed students' aptitude of recalling conception skills. Supplementary categories of skills like application, analysis, synthesis and evaluation are barely incorporated in the traditional appraisal. Some of the indispensable qualities are not included in the customary assessment system. This makes learners rely extremely on their memorization skill leading them to become helpless, deficient required excellence to contribute fruitfully to the society. The government of Fiji has a sensible vision for the stipulation of its education organization and has impartially arbitrated the Class-Based Assessment (CBA) aspirant for learners' holistic development. CBA has been implemented in secondary schools in 2009, through a pilot project. This research reveals the current status of the implemented assessment scheme through a study of a group of teachers of secondary schools and CBA resource personnel's from the Ministry of Education. It discusses the issues emerging from the arguments of the scholars regarding CBA and its potentiality in Fiji. Despite the popularity and wide acceptance of Class-Based assessment in the western countries and Fiji itself it has often been criticized for several reasons, most of them related to the utilitarian perspective and related ethical considerations. CBA seems to be very difficult to maintain within the stipulated time of teaching. It is difficult for the teachers to switch from summative assessment to formative one as it seems an extra assessment together with a final examination.
\end{abstract}

Keywords: Class-based assessment, Secondary school, Evaluation.

\title{
INTRODUCTION
}

Secondary education is one of the most important and prevalent sectors in education system having a gigantic number of schools and teachers. The innovations in teaching and learning at the Secondary school have established substantial attention. Generally, in Fiji Secondary schools, the examinations focus on testing students' aptitude to commit to memory what they have been taught in the class. Examining the students is all concerning helping the students. It consists of gathering substantiation about student accomplishment and with the confirmation to formulate decisions about them. Through a Cabinet decision in June 2009, Fiji Intermediate and Fiji Eighth Year Examinations were discontinued from 2010. This decision was based on connoisseur advice, findings and recommendations by the education commission report.

Education Commission Report (1969:p18), section 4.33 states that "By the occurrence and nature, the examinations have generally a daunting and deadening effect in that they limit the range and category of curricula and techniques of learning in the schools, without making the teachers confident in the examinations' effectiveness as measures of children's qualities". Education Commission Report 2000 p (360) notes that "Past years examination papers, rather than the curriculum of the textbook, are used by some teachers as the foundation for preparing students for the examination".

Assessment is not only about the examination and testing cognitive knowledge. It is to gain feedback and provide assistance to the students for their own learning. Robert Reinke (1998) states that "Learning that includes both intellectual and emotional components is effective as instruction touches the intelligence and assessment touches the compassion." An assessment system not only affects the learning and teaching but it also affects society as a whole. According to McNamara (2000), the impact of assessment can be complex and unpredictable. While talking about the impact of assessment, he also points out "part of the impact of the reform was to open the door to abuses of the assessment process by wealthy families, who could afford to hire private tutors to coach their children through the projects they had to complete in order to gain the scores they needed to enter the university of their choice". These studies reveal that the success of these changes greatly depends on whether or not the teachers feel they have the time, knowledge, material to achieve the goals and whether they received the training and encouragement to bring the change. A good number of researches and publications have focused on change in language assessment system, its impact and possibilities in developed countries.

According to Sophie\&Pavlow (2003: 4) "Interpretation of assessment is a general term which includes all methods used to gather information about children's knowledge, ability, understanding, attitudes and motivation. Assessment can be carried out through a number of instruments (for example, test, self-assessment), and can be formal or informal." This definition suggests that teachers may use both formal and informal methods to collect information in relation to learners' performance, such as their ability and attitudes, as an evidence of learning. Sophie (ibid) pointed out that assessment refers to all kinds of methods, whether they are formal or informal, with the aim of collecting evidences of learners' learning. 
The studies of Lambert and Lines 2000, suggest that assessment is a constant ongoing process rather than a one-time examination. It illustrates assessment as 'the general process of monitoring of keeping track of the learners' progress.' (p. 376). She highlights that such process is a continuous method to monitor the learners' performance. Wynne (2007) also show a similar point of view for assessment as the process of gathering, interpreting, recording and using information about pupils' responses to educational tasks. From their perspective, assessment is related to what teachers do during the process of teaching and learning, including gathering, diagnosing, recording and using information about pupils' performance and feedback. Thus, assessment is a part of both teachers' and students' life within the classroom is integrated into the process of teaching and learning. It is also used to scrutinize and respond to learners' regular work, such as learning activities, tasks and tests.

On the other hand, testing refers to a procedure that is used to measure learners' ability by teachers and examiners. According to David(2007), testing is a procedure with a certain objective and is used by teachers to assess learners' performance in order to understand whether the learner has achieved this objective or not. He also points out that testing 'used tasks or exercises and assigns marks or grades based on quantitative results' This seems to suggest that testing is one of the tools that used by teachers to assess their learners' ability and is a way to demonstrate what learners have learned. David and Debra 2006, also implies that testing is a onetime examination rather than an ongoing process. As can be seen, testing is a procedure with a certain objective and is used to collect quantitative results, in terms of marks or grades. It is used to measure what the learners have learned and to check whether they have met their goal or not; meanwhile, assessment refers to all methods of collecting both quantitative and qualitative data in relation to learners' performance and is a continuous process.

Furthermore, Penny 2006 describes that "classroom assessment or teacher assessment refers to an assessment carried out by teachers in the classroom" (p. 140). He also quotes that classroom assessment may be formative, for instance, when the purpose is to provide feedback to help learners improve learning, or it may be summative when the purpose is to record and report pupils' achievement and attainment (Pauline 2000). As can be seen, the purposes for classroom assessment may lead to using assessment information formatively or summatively by teachers. For example, they may need to use formative assessment to identify learner needs and use summative assessment to provide learners' achievement to school authorities at the end of a school year. In fact, there are a variety of purposes for teachers to use classroom assessment. Cheng, Rogers, \& Hu. (2004), suggests three objectives of using classroom assessment: 'teaching', 'nurturing learning', and 'measuring learning'.

However, to ensure a superior education scheme in Fiji, appropriate assessment methods was required along with an efficient syllabus. In 2010, the government instructed the schools across the country to carry out Class-Based Assessment (CBA) of secondary students at year 9 and 10 levels, instead of accessible assessing system that depended exclusively on examination. In other words, teachers may use classroom assessment to modify their teaching methods and materials, provide appropriate help to learners and meet the bureaucratic demands. With the introduction of the new assessment system, students' promotion to the subsequent class level will depend not only on examination results but also on their performance throughout the year and on their individual development.

Having experienced the obstacles in implementations of CBA while functioning at school, it was felt that it would be in the robustness of things if the other enthusiastic teachers' views were noted. The foremost rationale of this study was thus to unearth the current circumstances of CBA, teacher trainers 'and teachers' attitude towards it and the prospect of its accomplishment in bringing transformation in education in Fiji.

\section{OBJECTIVES}

Keeping in view the above issue concerning new system of assessment implemented in Fiji researchers have tried to-

i. To ascertain the attitudes of the teachers towards the new assessment system i.e. Class-Based Assessment

ii. To explore the challenges faced by teachers while implementing CBA.

\section{METHODOLOGY}

There are as many as 50 Secondary schools in the western division of Fiji. This study focused on Secondary Education in different schools of $\mathrm{Ba}$ which comprises from year 9 to year 13 classes. 8 teachers teaching year 9 and 10 were selected for accumulating information through a self-made questionnaire. 
The paraphernalia that was implored to collect statistics were in the form of interview and questionnaire. All the sources of information i.e. the answers to an interview survey, the transcripts of the semi-structured interview and the documents were constantly read through. Persistent themes regarding the CBA system were recognized and the information has proved to be very precious in understanding the issues under this study.

In this research, data were comprised of CBA trainers and Secondary school teachers. The teaching experience of the teachers varied from 6-22 years and their age ranged from 26 to 38 years. All the teachers were chosen purposively from the schools. The data were composed all the way through interview survey, semi-structured interviews and text analysis in this research. Open-ended questionnaires were disseminated among teachers and teacher trainers. Following the survey, semi-structured interviews were also taken with the teachers. The interview served teachers the purpose of exploring their estimation and the current situation of CBA. Most of the questions focused on participants' understanding of CBA and their attitude towards it. There were a number of questions that asked participants' inspiration and recommendation for its successful implementation. The trainers were also asked about their view concerning the potentiality and steps were taken for successful implementation of the new assessment system in Fiji.

These participants have been given pseudonyms to maintain their anonymity. Their names are used when their views are noted below. Information was also composed of current articles, syllabus, curriculum documents and government reports.

\section{RESULTS AND DISCUSSION}

The findings have been summarized under two main categories i.e. to identify the status of the new assessment system and to ascertain the attitudes of the teachers towards CBA. Secondly, it is to analyze teachers' efficiency towards CBA and to explore the challenges faced by teachers while implementing CBA

Class-based assessment is a form of continuous assessment which Fiji education system is employing. It includes. Standardized tests or classroom-based measures examine students reading, writing and recalling skills only. However, the use of CBA places emphasis on the process of actively teaching and learning, building students' skills for peer- and self-assessment, helping students understand their own learning, and develop appropriate strategies for "learning to learn".

CBA was implemented in all the schools in Fiji when NCF (National Curriculum framework) was introduced into the schools. The findings demonstrate that all the (100\%) trainers are very optimistic about changing the assessment system successfully. Survey also reveals that Head of the schools and few teachers were trained and been advised to inform other teachers about the implementation process of CBA i.e. preparation of task, rubrics, moderation and recordings. Head of the Departments has also been provided training for three days to train the assistant teachers to conduct the activities of assessment and organize the report. Head of the Departments was bestowed with the responsibility to verify every subject teacher's record keeping. Assurance of implementation procedure can be understood through a chain of activities conferred upon the officials of different ranks.

Teachers engaged their students in group work and assess their skills and clinched that if the students properly practice the prescribed activities and assessed through CBA, this will undeniably help the students to improve their overall skill progression. The majority $(90 \%)$ of the teachers stated that the students who are actively building their understanding of concepts (rather than merely absorbing information) developed a variety of strategies that enabled them to place new ideas into a larger context, developed judging skills, etc. that are priceless for learning throughout their lives.

Teachers felt strongly that continuous assessment enabled teachers to support lower attaining pupils to improve. $80 \%$ teachers found that using classroom-based assessment really helped them to plan for their students' learning needs and it shifts learning from teacher centered to child-centered resulting in students becoming more engaged in lessons. $20 \%$ of the teachers felt that the same can be done through the test, evaluate and take remedial and retest.

Among teachers, the junior teachers were more constructive in the use of CBA than the senior ones. If the teachers can plan their activities accordingly, CBA will be able to improve the quality of education in Fiji. Most of the participants (70\%) mentioned that teachers for the first time may not be able to recognize this change positively 
because while using traditional assessment method in Fiji, teachers rarely practice an oral presentation or do group works with the students.

Despite its popularity, CBA has often been criticized for several reasons, most of them related to the utilitarian perspective and related ethical considerations. Also, it is evident that CBA seems to be very difficult to maintain within the teaching time because the teachers took CBA as an extra assessment together with the examination. Therefore, it is difficult for the teachers to switch from summative assessment to formative one.

Additionally, reasons for being the repulsive attitude of the teachers towards CBA are the load, class size and the weightage of assessment over exams. The implementation of CBA has not removed examinations fully. There is more weightage (50-70\%, subject to the discipline) given for the exam rather than assessment through CBA (30$50 \%$ ) at the end of the year as for the final accreditation for students performance where students are being graded as basic proficient and advance. In addition to this political disruption, natural disasters, closures for board examinations and a range of scheduled holidays, unavailability of the resources on time are some of the factors which may often disrupt the CBA in the academic calendar.

Although the government has already implemented the new assessment system, most of the teachers have not got the training necessary for implementing such a project. Untrained teachers will have a deprived understanding of the ideas which will lead them to their inability to distribute the marks effectively. If these teachers try to implement such a new system, the system will collapse. If the CBA is implemented without providing adequate training to the teachers, a huge opening will be created between ministerial expectations and classroom authenticity.

\section{CONCLUSION}

Secondary education is one of the most significant and predominant sectors in the education system in Fiji. The assessment of the students is one of the approaches to measuring the effectiveness of the learning and teaching process which provides feedback for both the students and the teachers. Furthermore, assessments are done to accredit the students with scores and grades which helps the students and other stakeholders to access the eligibility of the students as per the required need. To ensure a superior education scheme in Fiji the government instructed the schools across the country to carry out Class-Based Assessment (CBA) of secondary students, instead of accessible assessing system that depended exclusively on examination.

With the application of CBA, teachers are getting great assistance to plan for their students' learning needs which moves to learn from teacher centered to child-centered. Though CBA is able to improve the quality of education in Fiji at the same time, it seems to be very difficult to maintain it within the teaching time because the teachers took CBA as an extra assessment together with the examination. Teachers for the first time may not be able to recognize this change positively because while using traditional assessment method in Fiji, teachers practice oral presentation or group works with the students only in few subjects.

Fiji Government commits to convey transformation in the assessment system. The success of the new assessment system will depend on the proper management of resources and manpower. Since the Government of Fiji and the benefactor countries have been pouring huge amount of money to convey changes in secondary education, we should anticipate that the government and the ministry of education may structure policies and execute practices after adequate consideration so that they can accomplish something to achieve the targets of implementing the new assessment system.

\section{References}

[1]. Cheng, L., Rogers, T., \& Hu, H. (2004). ESL/EFL instructors' classroom assessment practices: Purposes, methods and procedures.Language Testing, 21(3), 360-389.

[2]. Boud, D. and Falchikov, N. (2007). Introduction: assessment for the longer term. In Boud, D. \&Falchikov, N. (Eds.) Rethinking Assessment for Higher Education: Learning for the Longer Term. London: Routledge, 3-13. ISBNI0: 0415-39778-2.

[3]. David J. Nicol\& Debra M. (2006) Formative assessment and self-regulated learning: A model and seven principles of good feedback practice, Studies in Higher Education, 31(2), 199-218, doi: 10.1080/03075070600572090

[4]. David, L. \& David. L, (2000), Understanding Assessment ( ${ }^{\text {st }}$ ed.), Routledge/Falmer, Milton Park, Abingdon, Oxon, USA 
[5]. Essays, UK. (November 2013). Definitions of Assessment and Classroom Based Assessment English Language Essay. https://www.ukessays.com/essays/english-language/definitions-of-assessment-and-classroom-based-assessmentenglish-language-essay.php?vref

[6]. McNamara,T. (2000). Language Testing. Oxford University Press: New York.

[7]. Nilesh. A, N, (2014). Teachers' Perceptions towards Class Based Assessment. International Journal of Teacher Educational Research (IJTER) 3 (12), www.ijter.com.

[8]. Pauline, R. (2000). Classroom-Based Assessment: Possibilities and Pitfalls. In: Cummins J., Davison C. (Eds), International Handbook of English Language Teaching (pp. 103-110). Springer International Handbooks of Education, vol 15. Springer, Boston, MA.

[9]. Penny. M, (2006).Assessing Young Language Learners, Cambridge University Press, America.

[10]. Sophie. I, G \&Pavlow (2003), Assessing Young Learners (Ed.4), Oxford University Press, USA.

[11]. Wynne.H, (2007). Assessment for Learners, Replika Press Pvt. Limited, India. 